\title{
On the Construction of University Archives Informatization
}

\author{
Shumin Cui \\ Management of teaching and research base \\ Jilin Agricultural University \\ Changchun,,China \\ 729738677@qq.com \\ $+8615604305161$
}

\begin{abstract}
Accelerating the construction of university archives informatization is the objective requirements of standardization and modernization of university archives management. In order to promote the construction of university archives informatization, it is required to accurately understand the scientific connotation of informationization construction and grasp the central part of informatization construction. Appropriate measures should also be taken to implement the construction of university archives informatization effectively.
\end{abstract}

Key Words- university; archives informatization; construction

\section{INTRODUCTION}

The construction of university archives informatization is an inevitable trend of archival work to adapt the development of informatization development and it is also an indispensable tool for our country to enhance the ability of archival work to serve society. In recent years, various types of archive departments at all levels are vigorously promoting the construction of archives informatization and synchronizing archival work and social development. University is a place of intensive informatization technology. Accelerating the construction of university archives informatization to adapt to the need for university’s modern and standard management is the inevitable trend of time and social development.

\section{THE CONNOTATION AND IMPORTANCE OF THE CONSTRUCTION OF UNIVERSITY ARCHIVES INFORMATIZATION}

\section{A. The connotation of the construction of university archives informatization}

The construction of university archives informatization refers to the transformation of archive management mode from focusing on file entity custody to taking the digital information of file entity as the primary form to provide services to school and society. This definition raises several requirements: The digitization and networking of archival information should be achieved; The integration of receiving, transferring, storing and utilizing archival information should be achieved; The highly sharing of information should be achieved ${ }^{[1]}$.

\section{B. The importance of the construction of university} archives informatization

The archival information resources provide basis for teaching and research work of university. Materials such as lesson plans, curricula, professional setting, curriculum, teaching mode, programs and solutions formed from teaching reform and teacher training, typical lesson plans and lectures comments, statistical reports, comprehensive analysis of exam quality, tapes and CDs formed from multimedia teaching are recorded in teaching archives. The university enrollment archive also records the students' whole study process and score sheet, their graduation and completion of courses, teaching management and so on ${ }^{[2]}$. These information resources provide evidence for university's teaching management, teaching reform, scientific research, issuing graduation certificate, grade transcript and abroad certificate to students, etc.

\section{Problems EXISTING IN THE CONSTRUCTION OF UNIVERSITY ARCHIVES INFORMATIZATION}

\section{A. The shackles of traditional concepts}

In the information age, although people recognize the importance of the development and utilization of information resources, old and traditional values and mindset are still an enormous bondage in practice due to various factors. For a long time the Archive has been in a closed or semi-closed state and many people still lack adequate knowledge about the work of archive management.

\section{B. Outdated equipment and lack of funds}

In order to achieve an effective development and utilization of archival information resources, infrastructures adapting to their development needs must be equipped, such as computer hardware and software systems, text scanning systems, network systems, archive management software systems. Although most colleges and universities' archives are equipped with computers, the construction of archives informatization cannot be well equipped and technology cannot be well improved due to the insufficient funds. It results in the construction of archives informatization lags behind the demand of reality and the computer search, the access to archives, the network transmission of information, cannot be achieved, either ${ }^{[3]}$. Thus, the development and utilization of archives are greatly restricted, the working efficiency is influenced, and the process of archives informatization is hindered. 


\section{Lack of centralized standards including system standards and software standards of the construction of archives informatization}

On the basis of their own characteristics and in accordance with scientific, orderly, rigorous and efficient work requirements, universities should revise the archive management rules and formulate administrative documents such as "archive management approach of digital photo", "archive management approach of videotape", and “organizing orders of photo archive”, in order to guarantee a safe and orderly conduct of the construction of archives informatization. Therefore, in the process of the construction of archives informatization, the centralized management system and standards are needed to regulate the development and management of new information technologies and means.

\section{SUGGESTIONS FOR THE CONSTRUCTION OF UNIVERSITY ARCHIVES INFORMATIZATION}

\section{A. Enhance the awareness of university archives informatization}

School leaders should attach considerable importance to archives informatization, recognize its importance, strengthen the archival work in conformity with legal provisions, continue to strengthen the leadership of archival work, list archival work in the school's development plan, put it on the agenda, and increase the support and guarantee on the human resources, material resources, financial resources and time that are put on archival work to ensure the normal development of archival work. University Archives Department should further enhance the development and utilization of working responsibility and urgency and take effective measures to solve the existing problems. The management capacity and the development and utilization of archival information resources should also in continuously improved.

\section{B. Taking infrastructure construction as the prerequisite for the construction of university archives informatization}

Related hardware and database construction of the construction of archives informatization are basic premise to achieve university archives informatization. Under the support of school leaders and relevant departments, university archives should first focus on strengthening the construction of related hardware, such as equipping computer software and hardware systems, document scanning systems, microfilm systems, digital audio production systems and network systems. They should also develop and purchase software that is suitable to the work characteristics of university archives. Only with the relevant hardware infrastructure in accordance with the needs of archives informatization and with full-featured management software which is easy to operate and maintain, can advance conditions for the smooth development of archives management informatization be provided.

\section{Taking the construction of archive information resource as the foundation and guarantee for the construction of university archives informatization}

Enrich and optimize archival collections and highlighting features. Archives of every university should strive to improve the quality of archival organization, formulate the range of every department's archive material combined with its own practical situation, implement scientific analysis and planning on archive structure among the collection regularly, and plan the range of archive collection based on the historical need and the need of reality ${ }^{[4]}$.

Create a directory database and accomplish the collection of electronic documents. Promote the construction of all kinds of basic archival information repository and advance the process of digitizing traditional vector file based on the principle of “utilization first, step by step". University archives departments must first establish their own directory database of various archival types, on the basis of which, then they should promote gradually the information collection of full text and establish database of thematic text and database of multimedia files. At the same time, they should also do the following things: Intensify internal LAN construction; Use a standardized archive information management system; Establish standardized management of archives and the platform available to utilize; Strengthen the standardized construction; Unify data format and technical standards of management system; Ensure the smooth exchange of information and ease of sharing.

\section{To strengthen the construction of archives information} security system is to ensure the smooth running of the construction of university archives informatization

Strengthen the construction of archives information security system. When various departments of universities are promoting the use archive management system, they must put information security in a prominent position and implement state policies on strengthening information security work. Maintain the security of archives of confidentiality and protect archival information and intellectual property of information products. Safeguard the national interest and protect personal privacy. Only with the maintenance of the security of university archives, could the integrity of university archive information be better safeguarded. Archive information security capabilities could also be improved under the informatization condition.

\section{E. Strengthen the construction of archival personnel}

The key to promote development is people. Quality of archival management personnel directly affects the level of informatization. Archival work under the environment of informatization is a professional and highly technical work, which needs a high-quality archival cadre group. Therefore, the construction of professional archival personnel must be strengthened. According to the Extended Education Ordinance of professional and technical personnel, archival personnel should be actively supported to participate in various training programs in order to improve their professional qualities and working abilities ${ }^{[5]}$. Archivists 
need to enhance their own sense of responsibility, strive to broaden their knowledge, improve the knowledge structure, and improve the operational capacity to become experts in their own work field.

\section{REFERENCES}

[1] Greg Bak, Pam Armstrong. Points of convergence: seamless long-term access to digital publications and archival records at library and archives Canada[J]. Archival Science, 2008, 8 (4): 279-293.
[2] Livia Iacovino, Barbara Reed. Recordkeeping research tools in a multi-disciplinary context for cross-jurisdictional health records systems [J]. Archival Science, 2008, 8 (l): 37-68.

[3] Manion, Kevin. "Integrating Archives, Records, and Research", The Information Management Journal, 2005, 39 (1): 50-56.

[4] Silvia Schenkolewski-Kroll, Assaf Tractinsky. Archival Description, Information Retrieval, and the Construction of Thesauri in Israeli Archives [J].Archival Science, 2006, 6 (l): 69-107.

[5] Thomas Kirchhoff, Werner Schweibenz, Jorn Sieglerschmidt. Archives, libraries, museums and the spell of ubiquitous knowledge [J]. Archival Science, 2008,8 (4): 251-266 